\title{
The Impacts of Human Resources and Foreign Direct Investments to Vietnam's Economic Growth
}

\author{
Nguyen Van Huong ${ }^{1}$, Dang Quy Duong ${ }^{2} \&$ Do Thi Thu Thuy ${ }^{3}$ \\ ${ }^{1}$ Hung Yen University of Technology and Education, Vietnam \\ ${ }^{2}$ University of Economics and Business, Vietnam National University, Hanoi, Vietnam \\ ${ }^{3}$ School of Banking and Finance, National Economic University, Vietnam \\ Correspondence: Dang Quy Duong, University of Economics and Business, Vietnam National University, Hanoi, \\ Vietnam.
}

Received: October 3, 2018

Accepted: October 27, 2018 Online Published: November 25, 2018

doi:10.5539/jms.v8n4p125

URL: https://doi.org/10.5539/jms.v8n4p125

\begin{abstract}
Research on human resources, foreign direct investment and economic development are important issues in assessing the effectiveness of employment as well as attracting foreign direct investment (FDI) in the economy. In this study, the author analyzes the impact of human resource factors and FDI on economic growth in Vietnam from 1990 to 2017. By regression analysis based on the ARDL model, the result shows FDI has only a positive effect on economic growth in the short term but has the opposite effect in the long term. At the same time, unemployment rates have the opposite effect on economic growth in the short term. Average life expectancy does not affect economic growth in both the short and long term. From this result, the author also offers some suggestions for economic development in both the short and long term.
\end{abstract}

Keywords: human capital, life expectancy, unemployment, economic growth

\section{Introduction}

Foreign direct investment (FDI) has a positive impact on the economic growth of the invested country. FDI will help solve the problems of employment and technology transfer to the host countries (Gui-Diby, 2016). As of April 2017, Vietnam's FDI inflows were 3.2\% higher than in the same period of 2016. FDI not only helped to build up the buffer for foreign exchange but also helped push the economy toward production. Value added items are higher. After 30 years of attracting FDI, the proportion of FDI in total social investment accounts for about $25 \%$, contributes over $20 \%$ to GDP, and also accounts for the high proportion of the state budget. Total budget revenue (VEPR, 2017).

Human resources are the source of all development in society, even everyday services that are providing us, such as education, health, are also made by human resources, and the purpose of these services are also an important way of improving the quality of human resources for society to serve a common goal of socio-economic development.

There have been many researchers examining the impact of FDI on economic growth, and the results have also shown the positive effects of FDI on economic growth (Sunde, 2017; Adams, 2009; Meyer \& Nguyen, 2005). At the same time, there are studies that show that human capital has a positive effect on economic growth (Grossman, 1972; Shultz, 1961). Vietnam is in the process of attracting strong FDI in recent years, so the increase of FDI or human resources will help find the direction of FDI attraction or focus on developing human resources for economic development of the province further. Therefore, the author has implemented the topic "The impact of FDI and human capital on Vietnam's economic development".

\section{Literature Review and Research Method}

\subsection{Literature Review}

Nowadays the role of human resources is increasingly recognized as an important factor besides capital and technology for all growth. Besides, one of the requirements to integrate into the regional economy as well as the world is to have the human resources to meet the requirements of the development level of the region and the world. Human resources are all employees are able to participate in the process and the next generation will 
serve the society. Human resource as a factor of socio-economic development is the ability of the society to work in a narrower sense, including the working population in the working age.

Human resources can also be understood as the aggregation of individuals but specific people involved in the labor process, which is the totality of the physical and mental factors that are mobilized into the labor process. Under this understanding, workers include people below the age limit of employment. Human resources are the sum of the potentials, capacities, and abilities of each individual, of each community and of society as a whole, creating the development of society represented by factors such as education, subjects, work skills, living standards, health, and emotional thoughts. Among these factors, the two most important and widespread factors are employment and health.

Foreign Direct Investment (FDI) is a form of long-term investment of an individual or company in another country by setting up a business or production base. That individual or company will be in charge of managing this business.

The World Trade Organization provides the following definition of FDI: Foreign direct investment (FDI) occurs when an investor from a country (investor country) acquires an asset in another country ( the country attracts investment) along with the right to manage the property. The management aspect is to distinguish FDI from other financial instruments. In most cases, both the investor and the property he or she manages overseas are business establishments. In those cases, the investor is often referred to as the "parent company" and the assets are called "subsidiary" or "branch." In this study, the author defines direct investment Foreign Direct Investment (FDI) is the movement of capital, technology or any assets from foreign countries to invest in the host country to establish or control an enterprise for the purpose of profitable business.

\subsection{Research Method}

\subsubsection{Research Model}

The author uses Sunde's reference model (2017) to assess the impact of FDI on economic growth. In this paper, the author uses time series data to evaluate the impact of sudden changes as well as fluctuations in late stages (Duy, Kien, \& Tuyen, 2013). In order to solve the research objectives, the authors refer to the empirical studies and model the following research variables:

The author's model is as follows:

GDP $=\beta 0+\beta 1 * \mathrm{UEM}+\beta 2 * \mathrm{LE}+\beta 3 * \mathrm{FDI}+\varepsilon$

Dependent variable:

GDP: economic growth

Independent variables:

UEM: Unemployee

LE: Average life expectancy

FDI: Foreign direct investment

$\beta 0$ : constant

$\beta 1 ; \beta 2 ; \beta 3$ : Unknown parameters of the model.

$\varepsilon$ : white noise

\subsubsection{Data}

The author collects data on the World Bank database for indicators from 1990 to 2017. Vietnamese variables are collected and processed into the time series data to be input. Since the data is time series, Eviews software is considered suitable for analysis.

\subsubsection{Data Analysis}

For research purposes, the ARDL (AutoRegressive Distributed Lag) model is used for analysis based on EViews software

In fact, the ARDL model has been shown to be especially useful for describing the behavior of economic, financial and forecasting time series (Aydin, 2000). Based on this feature, the use of the ARDL model to study the impact of independent variables on dependent variables is appropriate (Hashem \& Yongcheol, 1997; Chen, 2007; Pasaran \& Shin, 1997). 
ARDL model:

$\mathrm{Yt}=\mathrm{m}+\alpha 1 \mathrm{Y}_{\mathrm{t}-1}+\alpha 2 \mathrm{Y}_{\mathrm{t}-2}+\ldots+\alpha n \mathrm{Y}_{\mathrm{t}-\mathrm{n}}+\beta 0 \mathrm{X}_{\mathrm{t}}+\beta 1 \mathrm{X}_{\mathrm{t}-1}+\ldots+\beta \mathrm{n} \mathrm{X}_{\mathrm{t}-\mathrm{n}}+\mathrm{ecm}_{\mathrm{t}-1}+\mathrm{ut}$

Study variables when running ARDL regression should be sure to stop. The stopping time series is the average, variance, covariance constant at all times (Gurajati, 2003). To test the continuity of the time series, the author uses Unit Root Test based on the extended ADF method (Gurajati, 2003).

The optimal delay is the latency at which the variables are modeled through the delay and other variables and the same latency for the best result. The optimum latency determination based on the selected indicators is supported in the EViews software.

The model has reliability or consistency when ensuring the following criteria: Model does not exist multi-collinear; no autocorrealtion and no heterodasticity.

\section{Result}

\subsection{Stationary Test}

Table 1. Test results of stationary of data series

\begin{tabular}{lll}
\hline & ADF-stats & p-value \\
\hline GGDP & -2.37318 & 0.1586 \\
FDI & -2.20001 & 0.2109 \\
UNEM & -3.94928 & 0.0059 \\
LE & -2.76442 & 0.0790 \\
\hline Sai phân bậc nhất & & \\
\hline GGDP & -4.32206 & 0.0025 \\
FDI & -3.77284 & 0.0089 \\
LE & -3.72243 & 0.0107 \\
\hline
\end{tabular}

The test result indicates that the UNEM variable is a stationary variable (the p-value of the ADF test is less than 0.05). The GGDP, FDI and LE are stationary at the first difference. With stop variables, the author proceeds to determine the optimal lag.

\subsection{Determine the Optimal Lag}

Table 2. Results of determine the optimal lag

\begin{tabular}{lllllll}
\hline Lag & LogL & LR & FPE & AIC & SC & HQ \\
\hline 0 & 5.992259 & NA & $9.88 \mathrm{E}-06$ & -0.17324 & 0.024237 & -0.12358 \\
1 & 53.73274 & 74.72423 & $6.43 \mathrm{E}-07$ & -2.93328 & -1.9459 & -2.68496 \\
2 & 92.27414 & $46.91997^{*}$ & $1.05 \mathrm{e}-07^{*}$ & -4.8934 & $-3.116108^{*}$ & -4.44642 \\
3 & 111.7697 & 16.95268 & $1.19 \mathrm{E}-07$ & $-5.197367^{*}$ & -2.63016 & $-4.551723^{*}$ \\
\hline
\end{tabular}

Indicators choose 3 as the optimal lag. Therefore, the author uses lag 3 for regression analysis.

\subsection{The Cointegration Test}

With the long-term relationship that may occur between the study variables, the author proceeds to use the Johansen test with unconfined variables. The results are as follows.

Table 3. The result of Johansen test

\begin{tabular}{lllll}
\hline $\begin{array}{l}\text { Hypothesized } \\
\text { No. of CE(s) }\end{array}$ & Eigenvalue & Trace & 0.05 & p-value \\
\hline None ${ }^{*}$ & 0.794627 & Statistic & Critical Value & 0.0001 \\
At most $1 *$ & 0.631277 & 71.67712 & 47.85613 & 0.017 \\
At most 2 & 0.328992 & 33.68686 & 29.79707 & 0.3011 \\
At most 3 & 0.006911 & 9.74182 & 15.49471 & 0.6833 \\
\hline
\end{tabular}


The results indicate that there is a long-term relationship between research variables. Thus, the author uses the ARDL model for regression analysis.

\subsection{Regression Analysis}

After the stationary variables, the author conducts the regression analysis. The results are as follows.

Table 4. The result of regression

\begin{tabular}{|c|c|c|c|c|}
\hline \multicolumn{5}{|l|}{ Short run } \\
\hline Variable & Coefficient & Std. Error & t-Statistic & Prob. \\
\hline FDI & 0.240054 & 0.420555 & 0.570803 & 0.5821 \\
\hline $\mathrm{FDI}_{\mathrm{t}-1}$ & -0.63891 & 0.58184 & -1.09808 & 0.3007 \\
\hline $\mathrm{FDI}_{\mathrm{t}-2}$ & 0.97668 & 0.465629 & 2.09755 & 0.0654 \\
\hline LE & 25.31072 & 72.18759 & 0.350624 & 0.7339 \\
\hline $\mathrm{LE}_{\mathrm{t}-1}$ & 127.1033 & 228.3755 & 0.556554 & 0.5914 \\
\hline $\mathrm{LE}_{\mathrm{t}-2}$ & -70.9101 & 84.43637 & -0.83981 & 0.4228 \\
\hline UNEM & 0.968241 & 0.605416 & 1.599299 & 0.1442 \\
\hline $\mathrm{UNEM}_{\mathrm{t}-1}$ & -0.44989 & 0.47868 & -0.93985 & 0.3718 \\
\hline $\mathrm{UNEM}_{\mathrm{t}-2}$ & -1.50976 & 0.525118 & -2.87509 & 0.0183 \\
\hline CointEq(-1) & -0.52156 & 0.152209 & -3.42658 & 0.0075 \\
\hline \multicolumn{5}{|c|}{ Cointeq $=$ GGDP $-(-3.4054 *$ LFDI $+1.7963 *$ LE $+6.1701 *$ UNEM -70.1315$)$} \\
\hline \multicolumn{5}{|l|}{ Long Run } \\
\hline Variable & Coefficient & Std. Error & t-Statistic & Prob. \\
\hline LFDI & -3.40541 & 1.427213 & -2.38606 & 0.0408 \\
\hline LE & 1.796302 & 1.22625 & 1.464875 & 0.177 \\
\hline UNEM & 6.170136 & 3.711176 & 1.662582 & 0.1308 \\
\hline $\mathrm{C}$ & -70.1315 & 66.97372 & -1.04715 & 0.3223 \\
\hline
\end{tabular}

The regression results for the ARDL model indicate that, in the short run, FDI has a positive impact on economic growth with lag 2 at $10 \%$ significance (p-value less than 0.1 and positive beta). The unemployment rate also has an impact on economic growth with lag 2 at $5 \%$ significance (p-value less than 0.05 and negative beta coefficient). The change in life expectancy has no impact on economic growth during the author's research period.

Regarding the long-term relationship, there is only a long-term relationship between economic growth and FDI. In particular, FDI has the opposite effect on economic growth at $5 \%$ significance (p-value less than 0.05 and negative beta coefficient). The variables of unemployment and life expectancy have no impact on long-term economic growth

\section{Discussion and conclusion}

FDI has a positive impact on economic growth; this result shows that FDI in Vietnam in the period 1990 to 2017 is economically efficient. FDI into Vietnam has solved the problems that a developing country like Vietnam has been experiencing (unemployment, income for economy, production technology ...). The big FDI enterprises such as samsung have made great contributions to creating jobs as well as professional working environment and modern equipment. Investments in FDI have no immediate impact on economic growth but only have a positive impact in the short to medium term after the investment is two years.

The factor of unemployment that has the opposite effect on economic growth shows that the increase in the number of unemployed leads to reduced income generating work. This leads to a decline in economic growth. In contrast, the economy that creates more jobs will increase incomes. The increase in spending also increases the contribution of GDP as well. At the same time, the unemployment rate in the year did not cause the state of health of the economy to decline right in that year, and then 2 years after the new economic growth is affected.

The regression analysis using the ARDL model has shown the unemployment rate has the opposite effect on economic growth between 1990 and 2017. Therefore, for more economic growth, policy makers need to focus on reducing the unemployment rate by creating more jobs for people by investing in expanding projects that give people more opportunities to work. At the same time actively attract and facilitate foreign investment enterprises in Vietnam in the coming years when the country is on the rise. This increases the amount of labor needed in the country and at the same time creates qualified human resources and high income by working in foreign businesses. 
At the same time, because FDI has a positive impact on economic growth in the short-term, the attraction of FDI in the next 10 years still needs attention. However, in the long run, FDI has the opposite effect on Vietnam's economic growth. As a result, it seems that the FDI enterprises and Vietnam, due to the preferential policies, cheap labor and the transfer of technology, are not paid much attention by FDI enterprises. FDI needs to be changed in relation to technology transfers and new technologies. Capture the new technology and master the technology, the country can develop in the long term when attracting FDI.

\section{References}

Adams, S. (2009). Can foreign direct investment (FDI) help to promote growth in Africa? African Journal of Business Management, 3(5), 178.

Aydin, H. I. (2007). Interest Rate Pass-Through in Turkey. Research and Monetary Policy Department, 07(05), $1-38$.

Chen, M. A. (2007). Rethinking the informal economy: linkages with the formal economy and the formal regulatory environment. Working Paper, 46, United Nations, Department of Economic and Social Affairs.

Duy, N. V., Kien, D. T., \& Tuyen, B. Q. (2013). Influence of foreign direct investment on Vietnam's economic growth in the period 1990-2013 by ARDL model. Journal Scientific and Training, 1, 59-67.

Gui-Diby, S. L. (2016). Essays on the Impact of Foreign Direct Investments in Africa. Universite d' Auvergne-Clermont-Ferrand I. Retrieved from https://tel.archives-ouvertes.fr/tel-01282942/

Gurajati, D. N. (2003). Basic Econometrics. McGraw Hill.

Grossman, M. (1972). The demand for health: a theoretical and empirical investigation. NBER Books.

Meyer, K. E., \& Nguyen, H. V. (2005). Foreign investment strategies and sub-national institutions in emerging markets: Evidence from Vietnam. Journal of Management Studies, 42(1), 63-93. https://doi.org/10.1111/j.1467-6486.2005.00489.x

Pasaran, H. H., \& Shin, Y. (1997). Generalized impulse response analysis in linea multivariate models. Economic Letters, 58, 17-29. https://doi.org/10.1016/S0165-1765(97)00214-0

Shultz, A. R. (1961). Degradation of polymethyl methacrylate by ultraviolet light. The Journal of Physical Chemistry, 65(6), 967-972. https://doi.org/10.1021/j100824a019

Sunde, T. (2017). Foreign direct investment and economic growth: ADRL and causality analysis for South Africa, Research in International Business and Finance, 41, 434-444

VEPR. (2017). Annual report.

\section{Copyrights}

Copyright for this article is retained by the author, with first publication rights granted to the journal.

This is an open-access article distributed under the terms and conditions of the Creative Commons Attribution license (http://creativecommons.org/licenses/by/4.0/). 